\title{
R Factors from Proteus mirabilis and $P$. vulgaris
}

\author{
By R. W. HEDGES \\ Bacteriology Department, Royal Postgraduate Medical School, \\ London WI2 oHS
}

(Received 23 September 1974)

\section{SUMMARY}

Eighty-nine R factors were transmitted by conjugation to Escherichia coli $\mathrm{K} 12$ from isolates of Proteus hauseri ( $P$. mirabilis plus $P$. vulgaris). More than half were non-selftranmissible. The remainder included plasmids assigned to the previously defined groups FII, A-C complex, J, N and P, as well as some not belonging to any known compatibility groups. $\mathrm{R}$ factors from strains isolated in India, Thailand and Japan carried plasmids whose inheritance was extremely unstable in $E$. coli KI2. All belonged to a new compatibility group, V.

\section{INTRODUCTION}

Swarming Proteus isolates are regarded either as constituting a single species (Proteus hauseri) (Kauffmann, I95I) or two distinct species ( $P$. mirabilis and P. vulgaris) (Hauser, I885). The question of their separability was discussed by Coetzee (1972). Clearly, even if two species are distinguished they are closely related: they share antigens including phage and bacteriocin receptors (Coetzee, 1972); some, at least, of their enzymes are serologically indistinguishable (Guo \& Liu, 1965; Smit \& Coetzee, 1967); and they show extensive homology in DNA:DNA hybridization tests (Brenner \& Falkow, 197I; Coetzee, 1972).

Thus, the group may be considered as a single species or as two closely related species, perhaps constituting a subgenus (Kauffman, 1956). For the purpose of this paper no distinction will be drawn between $P$. mirabilis and $P$. vulgaris, and strains will be referred to as ' $P$. mirabilis/P. vulgaris'.

Several reports of natural isolates of $P$. mirabilis/P. vulgaris carrying $\mathrm{R}$ factors appeared during the mid I960s. These are listed by Coetzee (I972). This work was undertaken to compare the $\mathrm{R}$ factor set from $P$. mirabilis/ $P$. vulgaris with those of $P$. rettgeri (Coetze, Datta $\&$ Hedges, 1972), P. morganii (Hedges, Datta, Coetzee \& Dennison, 1973) and Providencia (Hedges, 1974).

\section{METHODS}

Proteus mirabilis/P. vulgaris. About 1000 cultures, donated by laboratories from many different countries, were tested as $\mathrm{R}$ factor donors.

PmI3 (Coetzee \& Sacks, 1960; Coetzee, I963) was selected as a standard host for compatibility determination in this species. Two strains were selected for this purpose, Pmi3-A which carries a spontaneous mutation to nalidixic acid resistance, and PmI 3-B which carries a spontaneous rifampicin resistance mutation.

Escherichia coli $\mathrm{KI} 2$ strains $\mathrm{J}_{53}-\mathrm{I}\left(\mathrm{F}^{-}\right.$pro met nal $\left.{ }^{\mathrm{R}}\right), \mathrm{J}_{53}-2\left(\mathrm{~F}^{-}\right.$pro met rif $\left.{ }^{\mathrm{R}}\right)$ and $\mathrm{J} 62$ ( $\mathrm{F}^{-}$pro his trp lac) were used (Hedges et al. 1973).

Phage was phage PRRI (Olsen \& Shipley, 1973). 


\section{Table I. Standard plasmids}

\begin{tabular}{|c|c|c|c|}
\hline Plasmid & $\begin{array}{l}\text { Com- } \\
\text { patibility } \\
\text { group }\end{array}$ & $\begin{array}{l}\text { Genetic } \\
\text { markers* }\end{array}$ & Reference \\
\hline Flac & FI & $\mathrm{lac}^{+}$ & Jacob \& Adelberg (I959) \\
\hline R386 & FI & $\mathrm{T}$ & Dennison (1972) \\
\hline $\mathrm{R}_{\mathrm{I}} d r d \mathrm{I} 6$ & FII & $\mathbf{K}$ & Meynell \& Datta (1967) \\
\hline RI-I & FII & $\mathrm{A}, \mathrm{S}, \mathrm{C}, \mathrm{Su}$ & Hedges et al. (1973) \\
\hline $\mathrm{R}_{136}$ & FII & $\mathrm{T}$ & Lawn, Meynell, Meynell \& Datta (1967) \\
\hline ColB-K98 & FIII & colB & \\
\hline RI 24 & FIV & $\mathrm{T}$ & Hedges \& Datta (1972) \\
\hline Folac & FV & $\mathrm{lac}^{+}$ & Datta (1974) \\
\hline RAI & A & $\mathrm{T}, \mathrm{Su}$ & Hedges \& Datta (I97I) \\
\hline RAI-I b & A & $\mathrm{C}, \mathrm{Su}$ & Datta \& Hedges (1973) \\
\hline R57b & $\mathrm{C}$ & $\mathrm{A}, \mathrm{C}, \mathrm{Gk}, \mathrm{Su})$ & \\
\hline R57b-I & $\mathrm{C}$ & $\mathrm{C}, \mathrm{Su}$ & Datta \& Hedges (1972G) \\
\hline R4oa & $\mathrm{C}$ & $\mathrm{A}, \mathrm{K}, \mathrm{Su}$ & \\
\hline R27 & $\mathbf{H}$ & $\mathrm{T}$ & Grindley, Grindley \& Anderson (1972) \\
\hline R726 & $\mathbf{H}$ & $\mathrm{S}, \mathrm{T}, \mathrm{C}, \mathrm{Su}$ & \\
\hline R726-I & $\mathbf{H}$ & $\mathrm{S}, \mathrm{C}, \mathrm{Su}$ & Datta \& Olarte (I974) \\
\hline R64 & $\mathrm{I} \alpha$ & $\mathrm{S}, \mathrm{T}$ & \\
\hline RI44 & $\mathrm{I} \alpha$ & $\mathrm{T}, \mathrm{K}$, colI $\mathrm{b}$ & \\
\hline R648 & $\mathbf{I} \alpha$ & $\mathrm{A}, \mathrm{S}, \mathrm{K}$ & Hedges \& Datta (1973) \\
\hline $\mathrm{R}_{483}$ & $\mathbf{I} \beta$ & $\mathrm{S}, \mathrm{Tp}$, colla & \\
\hline R62Ia & $\mathbf{I} \gamma$ & $\mathrm{T}$ & \\
\hline R62Ia-I & $\mathrm{I} \gamma$ & $\mathrm{A}, \mathrm{T}, \mathrm{C}, \mathrm{K}$ & Hedges (1974) \\
\hline R62Ia-Ia & $\mathrm{I} \gamma$ & $\mathrm{A}, \mathrm{C}, \mathrm{K}$ & Segregant of R62Ia-I \\
\hline R39I & J & $\mathrm{K}$ & Coetzee et al. (1972) \\
\hline R387 & $\mathbf{K}$ & $\mathrm{S}, \mathrm{C}$ & Hedges \& Datta (1971) \\
\hline R472 & $\mathbf{L}$ & A & \\
\hline R83i & $\mathbf{L}$ & $\mathrm{S}, \mathrm{K}$ & Hedges, Rodriguez-Lemoine \& Datta (1974b) \\
\hline R47I & $\mathbf{L}$ & $\mathrm{A}, \mathrm{C}, \mathrm{K}$ & \\
\hline R446b & $\mathbf{M}$ & $\mathrm{S}, \mathrm{T}$ & Hedges et al. (1973) \\
\hline $\mathbf{R}_{\mathrm{IP}} 69$ & $\mathbf{M}$ & $\mathrm{A}, \mathrm{T}, \mathrm{K}$ & Witchitz \& Gerbaud (I972) \\
\hline $\mathrm{R}_{\mathrm{IP}} \mathbf{3 5}$ & $\mathbf{M}$ & $\mathrm{S}, \mathrm{T}, \mathrm{G}, \mathrm{Su} \quad\}$ & Witchitz \& Gerbaud (1972) \\
\hline $\mathrm{R} 447 \mathrm{~b}$ & $\mathbf{N}$ & $\mathrm{A}, \mathrm{K}$ & Hedges et al. (1973) \\
\hline $\mathrm{N}_{3} \mathrm{~T}$ & $\mathbf{N}$ & $\mathrm{T}$ & Hedges (I972) \\
\hline R390 & $\mathbf{N}$ & $\mathrm{A}, \mathrm{S}, \mathrm{T}, \mathrm{C}, \mathrm{Su}$ & Coetzee et al. (1972) \\
\hline $\mathrm{R}^{16}$ & $\mathrm{O}$ & $\mathrm{A}, \mathrm{S}, \mathrm{T}, \mathrm{Su}$ & Datta \& Olarte (1974) \\
\hline $\mathrm{R}^{16}-\mathrm{I}$ & $\mathrm{O}$ & $\mathrm{S}, \mathrm{Su}$ & Hedges (1974) \\
\hline $\mathrm{R}_{724}$ & $\mathrm{O}$ & $\mathrm{S}, \mathrm{T}, \mathrm{C}, \mathrm{Su}$ & Datta \& Olarte (I974) \\
\hline $\mathrm{RP}_{4}$ & $\mathbf{P}$ & $\mathrm{A}, \mathrm{T}, \mathrm{K}$ & Datta et al. (I97I) \\
\hline R75I & $\mathbf{P}$ & $\mathrm{Tp}$ & Jobanputra \& Datta (1974) \\
\hline R906 & $\mathbf{P}$ & $\mathrm{A}, \mathrm{S}, \mathrm{Su}$ & Hedges, Jacob \& Smith (I974a) \\
\hline R478 & S & $\mathrm{T}, \mathrm{C}, \mathrm{K}$ & Hedges et al. (1974b) \\
\hline R477-I & $\mathbf{S}$ & $\mathrm{S}, \mathrm{T}, \mathrm{Su}$ & Hedges et al. (1974b) \\
\hline Rts I & $\mathrm{T}$ & $\mathrm{K}$ & \\
\hline R40I & $\mathbf{T}$ & $\mathrm{A}, \mathrm{S}$ & Coetzee et al. (1972) \\
\hline R388 & $\mathrm{W}$ & $\mathrm{Tp}, \mathrm{Su}$ & Datta \& Hedges $(1972 b)$ \\
\hline R6K & $\mathbf{X}$ & A, S & Kontomichalou, Mitani \& Clowes (1970) \\
\hline PICM & Y & $\mathrm{C}$ & Ikeda \& Tomizawa (I968); Smith (1972); \\
\hline$\phi \mathrm{Amp}$ & Y & A & $\begin{array}{l}\text { J. R. Scott \& R. W. Hedges (unpublished); } \\
\text { M. Yarmolinsky (unpublished). }\end{array}$ \\
\hline
\end{tabular}

* $\mathrm{A}=$ ampicillin, $\mathrm{S}=$ streptomycin, $\mathrm{T}=$ tetracycline, $\mathrm{C}=$ chloramphenicol, $\mathrm{K}=$ kanamycin, $\mathrm{Gk}=$ gentamicin and kanamycin, $\mathrm{G}=$ gentamicin, $\mathrm{Su}=$ sulphonamides, $\mathrm{Tp}=$ trimethoprim. 
Table 2. Drug sensitivity patterns of $P$. mirabilis/P. vulgaris isolates

$\begin{array}{rr}\text { No. } & \text { Percentage } \\ \text { I I } 8 & 59 \\ \text { I0 } & 5 \\ 8 & 4 \\ 2 & \text { I } \\ 4 & 2 \\ 23 & \text { I I } \\ \text { I } & <\text { I } \\ \text { I } & <\text { I } \\ 0 & 0 \\ 0 & 0 \\ 6 & 3 \\ 20 & \text { IO } \\ \text { I } & <\text { I } \\ 5 & 2 \\ 3 & \text { I } \\ 202 & \end{array}$

$\begin{array}{rr}\text { No. } & \text { Percentage } \\ 324 & 8 \text { I } \\ 27 & 7 \\ 25 & 6 \\ 6 & \text { I } \\ \text { I } & <\text { I } \\ 7 & 2 \\ 0 & 0 \\ 0 & 0 \\ 2 & <\text { I } \\ 3 & \text { I } \\ 5 & \text { I } \\ 0 & 0 \\ 0 & 0 \\ 0 & 0 \\ 0 & 0 \\ 400 & \end{array}$

\begin{tabular}{|c|c|}
\hline \multicolumn{2}{|c|}{ Vancouver } \\
\hline No. & Percentage \\
\hline 45 & 28 \\
\hline 24 & I5 \\
\hline IO & 6 \\
\hline 2 & I \\
\hline 42 & 26 \\
\hline 5 & 3 \\
\hline I & $<\mathrm{I}$ \\
\hline 30 & I9 \\
\hline 0 & 0 \\
\hline 0 & 0 \\
\hline 0 & 0 \\
\hline I & $<I$ \\
\hline 0 & 0 \\
\hline 0 & 0 \\
\hline 0 & 0 \\
\hline 160 & Total \\
\hline
\end{tabular}

Phenotype resistances*

* For abbreviations see Table I.

Sensitive

A

$\mathrm{Su}$

S

$\mathrm{K}$

$\mathrm{S}, \mathrm{Su}$

$\mathrm{S}, \mathrm{K}$

$\mathrm{K}, \mathrm{Su}$

A, $\mathrm{S}$

A, $\mathrm{K}$

A, S, Su

$\mathrm{S}, \mathrm{K}, \mathrm{Su}$

A, S, C, Su

$\mathrm{A}, \mathrm{S}, \mathrm{K}, \mathrm{Su}$

A, S, C, K, Su

Plasmids are listed in Table I.

Techniques were as described by Datta et al. (1971), Dennison (1972) and Coetzee et al. (1972).

\section{RESULTS AND DISCUSSION}

Resistance patterns of $P$. mirabilis/P. vulgaris isolates

Approximately 1000 separate $P$. mirabilis/P. vulgaris isolates from a wide range of geographical soures were tested for drug resistance. Almost all $P$. mirabilis/P. vulgaris isolates are insensitive to tetracycline and polymixin, so these drugs were not included in the present investigation. The drugs used were ampicillin, streptomycin, chloramphenicol, kanamycin, gentamicin, trimethoprim and sulphadimidine.

Many of the cultures tested were selected by the bacteriologists who isolated the $P$. mirabilis/P. vulgaris strains as showing atypical drug resistance patterns and hence likely to carry $\mathrm{R}$ factors. Thus, the resistance patterns of the complete collections are not representative of the group. However, large collections of unselected isolates were available from three sources: Dr H. Gaya, Hammersmith Hospital, London; Professor M. Finland, Boston City Hospital, Massachusetts, U.S.A.; and Mrs R. Dobrey and Miss C. Malcolm, Shaughnessy Hospital, Vancouver, British Columbia, Canada. The resistance phenotypes of the cultures from these collections are listed in Table 2.

The marked differences in the resistance patterns of three groups and the differences between these and the patterns reported from by other authors from other sources (e.g. Tomaschoff, I969; Chai \& Soo-Hoo, 1970; Dikyi, 1972; von Graeventiz \& Nourbakhsh, 1972) indicates that, as is the case with Serratia marcescens (Hedges et al. 1974b) the $P$. mirabilis/P. vulgaris populations of different hospitals are often distinct. This is confirmed by the differences between the specificities of $\mathbf{R}$ factors from the different sources (Table 3). 
Table 3. $R$ factors from $P$. mirabilis/P. vulgaris

Plasmid

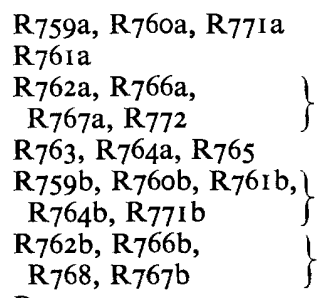

R393

R492, R493

R494, R842, R843

R490, R49I

R774, R841

R873, R9I I

R874

R908, R909, R910,

R92 I, R94I, R942,

R943, R944, R945

Plac*

Rts I*

R22Ka*

R22Kb*

R436a, R437a, R438, )

R439, R440

R436b, R437b

$\mathrm{R}_{468}, \mathrm{R}_{469}$

R470

R704a

R704b

R959

R645

R665

R682, R683, R684

R70 I

R702

R705, R706

R753, R754,

R755, R756

R757a

R757b, R758

R769, R770

R866, R867, R868

R869, R870

R87I

R901, R902, R903

R904

R905

R940
Source

Prof. M. Finland (Boston)

Prof. M. Finland (Boston)

Prof. M. Finland (Boston)

Prof. M. Finland (Boston)

Prof. M. Finland (Boston)

Prof. M. Finland (Boston)

Dr H. Gaya (London)

Dr H. Gaya (London)

Dr H. Gaya (London)

Dr H. Gaya (London)

Miss C. Malcolm (Vancouver)

Miss C. Malcolm (Vancouver)

Miss C. Malcolm (Vancouver)

Prof. S. Falkow (Seattle)

Dr M. Yoshikawa (Tokyo)

Dr P. Kontomichalou (Athens)

Dr P. Kontomichalou (Athens)

Dr E. J. L. Lowbury (Birmingham)

Dr E. J. L. Lowbury (Birmingham)

Dr F. Anderson (London)

Dr F. Anderson (London)

Dr F. Anderson (London)

Dr F. Anderson (London)

Dr F. Anderson (London)

Dr I. Phillips (London)

Dr E. Tomaschoff (Dusseldorf)

Dr E. Tomaschoff (Dusseldorf)

Dr F. Sabatelli (Bloomfield, U.S.A.)

Dr F. Sabatelli (Bloomfield, U.S.A.)

Prof. J. N. Coetzee (Pretoria)

Prof. S. Falkow (Ching Mai, Thailand)

Prof. S. Falkow (Ching Mai, Thialand)

Prof. S. Falkow (Ching Mai, Thailand)

Dr C. K. J. Paniker (Kerala, India)

Dr M. Lachmajer (Gdansk, Poland)

Dr M. Lachmajer (Gdansk, Poland)

Dr J. N. Wilfert (Salt Lake City)

Prof. S. Mitsuhashi (Maebashi, Japan)

Prof. S. Mitsuhashi (Maebashi, Japan)

Prof. S. Mitsuhashi (Maebashi, Japan)

Miss M. M. Moody (Bethesda, Md., USA)
Resistances $\dagger$

$\begin{array}{ll}\text { A, S, K } & \text { N } \\ \text { A, S } & \text { N } \\ \mathrm{K}\left(t r a^{-}\right) & \ddagger \\ \mathrm{A}, \mathrm{S}, \mathrm{T} & \ddagger \\ \mathrm{S}, \mathrm{Su}\left(t r a^{-}\right) & \end{array}$

$\mathrm{Su}\left(\right.$ tra $\left.^{-}\right)$

$\mathrm{S}$

$\mathrm{A}\left(\right.$ tra $\left.^{-}\right)$

$\mathrm{A}, \mathrm{T}, \mathrm{K}$

$\mathrm{Su}\left(\operatorname{tra}^{-}\right)$

$\mathrm{Su}\left(t r a^{-}\right)$

$\mathrm{S}, \mathrm{Su}\left(\mathrm{tra}^{-}\right)$

$\mathrm{K}\left(\right.$ tra $\left.^{-}\right)$

$\mathrm{Su}$

K

$\mathrm{A}\left(\mathrm{tra} \mathrm{a}^{-}\right)$

$\mathrm{S}$

A, T, K

$\mathrm{S}, \mathrm{Su}\left(\right.$ tra $\left.{ }^{-}\right)$

$\mathrm{K}\left(\mathrm{tra} \mathbf{a}^{-}\right)$

$\mathrm{Su}\left(\mathrm{tra}^{-}\right)$

$\mathrm{A}, \mathrm{S}, \mathrm{C}, \mathrm{K}, \mathrm{Su}$

$\mathrm{T}, \mathrm{Su}$

A, S, Su(tra $)$

A, S, Su(tra-)

$\mathrm{A}, \mathrm{Su}$

$\mathrm{S}, \mathrm{Su}\left(t r a^{-}\right)$

A, S, K

$\mathrm{S}, \mathrm{T}, \mathrm{K}, \mathrm{Su}$

K

A, S, C, Su

$\mathrm{A}, \mathrm{S}, \mathrm{Su}$

$\mathrm{S}, \mathrm{Su}\left(t r a^{-}\right)$

$\mathrm{S}, \mathrm{C}, \mathrm{K}, \mathrm{Su}$

A $\left(\right.$ tra $\left.{ }^{-}\right)$

A, S, Su(tra-)

$\mathrm{Su}$

$\mathrm{S}, \mathrm{C}, \mathrm{K}, \mathrm{Su}$

$\mathrm{S}, \mathrm{Su}\left(\right.$ tra $\left.^{-}\right)$

$\mathrm{S}, \mathrm{C}, \mathrm{Su}$

A, S, T, K, Su
Compatibility

$\mathbf{N}$

$N$

t.

$\ddagger$

$N$

FII

A-C complex

$\mathrm{T}$

N

P

FII

A-C complex

A-C complex

N

$\mathbf{P}$

$\mathbf{J}$

$\mathrm{V}$

V

V

A-C complex V

V

P

* These plasmids were transferred from $P$. mirabilis/P. vulgaris strains before being sent to Hammersmith.

$+\mathrm{tra}^{-}=$non selftransmissible (NST). For other abbreviations see Table I.

¥ See text. No attempt has been made to determine the incompatibility relationships of the NST R factors. 


\section{Transfer of resistance determinants from P. mirabilis/P. vulgaris to Escherichia coli $\mathrm{KI} 2$}

Natural isolates of $P$. mirabilis/P. vulgaris showing resistance to any of the antibiotics under investigation were grown with cultures of $E$. coli $\mathrm{KI}_{2} \mathrm{~J}_{5} 3^{-\mathrm{I}}$ or $\mathrm{J} 53^{-2}$ and any $\mathrm{R}^{+}$ $E$. coli transcipients were purified on MacConkey agar. The transferred resistance factors are listed in Table 3.

Plasmid-carrying strains of $\mathrm{J}_{53} \mathrm{-I}$ and $\mathrm{J}_{53}-2$ were incubated with cultures of $\mathrm{J} 62$. Plasmids which either were not transferable to J62, or which did transfer to this strain but at least $10 \%$ of whose transcipients were not capable of transfering the resistances to further $E$. coli $\mathrm{KI} 2$ strains, were considered to be non-selftransmissible (NST).

One of the most striking features of the $\mathrm{R}$ factor set from $P$. mirabilis/P. vulgaris is the remarkably high proportion of NST plasmids; of $89 \mathrm{R}$ factors transferred from $P$. mirabilis/P. vulgaris strains 48 were NST. This contrasts with a single NST plasmid among 105 from Providencia isolates (Hedges, 1974), 5 of 28 from Proteus morganii (Hedges et al. 1973) and none of 28 from Serratia marcescens (Hedges et al. 1974b).

The high proportion of NST plasmids among the set transferred from P. mirabilis/ $P$. vulgaris implies the presence of transfer factors (not, themselves, conferring drug resistances) in an appreciable proportion of $P$. mirabilis/ $P$. vulgaris isolates. In conformity with this conclusion, Mitsuhashi (I969) reported the detection of transfer factors in several isolates of Proteus (species not recorded).

Numerous authors (for references and discussion see Coetzee, 1972) have concluded that certain R factors, which in E. coli exist as single DNA molecules (composites), dissociate in $P$. mirabilis/P. vulgaris strains into transfer factors (Cohen \& Miller, 1970) and presumably into non-selftransmissible plasmids, carrying the resistance genes, which replicate under relaxed control. It is tempting to postulate that the NST plasmids and transfer factors are derived from such dissociated R factors. Studies on DNA homologies of such plasmids may provide evidence.

Since investigation of the compatibility properties of NST plasmids has been undertaken by Smith, Humphreys \& Anderson (1974), compatibility properties of NST plasmids from $P$. mirabilis/P. vulgaris will be described only in those cases where an NST plasmid showed interaction with self-transmissible factors.

The DNA molecules of several of the NST $P$. mirabilis/P. vulgaris plasmids have been investigated (Barth \& Grinter, 1974; S. Falkow, personal communication). They have been found to be small (molecular weight less than $10^{6}$ daltons), and similar to those described by Milliken \& Clowes (1973), Smith et al. (1974) and Barth \& Grinter (1974).

$\mathrm{R} 22 \mathrm{Ka}$, an NST plasmid determining a $\beta$-lactamase very similar to that of the $E$. coli chromosome, is an exception. This is a plasmid of molecular weight $6.05 \times 10^{7}$ whose replication is subject to stringent control. Its properties have been described by M. M. Bobrovski and others (unpublished).

\section{Properties of the self-transmissible plasmids}

$R 494, R 842, R 843$ and $R 704 a$. These plasmids are all members of group FII. The first three are apparently identical $R$ factors, all from Hammersmith Hospital. They have surface exclusion of the same specificity as R444 (Hedges et al. 1973). R704a, from The West Middlesex Hospital, London, closely resembles RI. 
Table 4. Reduction of rate of transfer of $P$ group plasmids by $R$ factors of group $I \alpha$

The recipient was always $\mathbf{3 6 2}$.

\begin{tabular}{|c|c|c|}
\hline Donor & $\begin{array}{l}\text { Drug used } \\
\text { in selection* }\end{array}$ & Efficiency of transfer \\
\hline J53(RP4) & $\begin{array}{l}\mathrm{T} \\
\mathrm{K}\end{array}$ & $\begin{array}{l}\mathrm{I} \times \mathrm{IO}^{-3} \\
\mathrm{I} \times \mathrm{IO}^{-3}\end{array}$ \\
\hline $\begin{array}{l}\mathrm{J} 53(\mathrm{RP} 4)(\mathrm{R} 64) \\
\mathrm{J} 53(\mathrm{RP} 4)(\mathrm{R} 648)\end{array}$ & $\begin{array}{l}\mathrm{K} \\
\mathrm{T}\end{array}$ & $\begin{array}{l}1 \times 10^{-5} \\
2 \times 10^{-5}\end{array}$ \\
\hline $\mathrm{J}_{53}(\mathrm{R} 702)$ & $\begin{array}{l}\mathrm{T} \\
\mathrm{K}\end{array}$ & $\begin{array}{l}7 \times 10^{-4} \\
9 \times 10^{-4}\end{array}$ \\
\hline $\begin{array}{l}\mathrm{J} 53(\mathrm{R} 702)(\mathrm{R} 64) \\
\mathrm{J} 53(\mathrm{R} 702)(\mathrm{R} 648)\end{array}$ & $\mathrm{K}$ & $\begin{array}{l}1 \times 10^{-5} \\
1 \times 10^{-5}\end{array}$ \\
\hline $\begin{array}{l}\mathrm{J} 53(\mathrm{R} 940) \\
\mathrm{J} 53(\mathrm{R} 940)(\mathrm{R} 64)\end{array}$ & $\begin{array}{l}\mathbf{K} \\
\mathbf{K}\end{array}$ & $\begin{array}{l}4 \times 10^{-3} \\
7 \times 10^{-5}\end{array}$ \\
\hline
\end{tabular}

In that their $\mathrm{R}$ factor set includes FII plasmids, $P$. mirabilis/P. vulgaris resembles P. morganii.

R22Kb, R393, R701, R759a, R760a, R76I $a$ and R77Ia. Proteus mirabilis/P. vulgaris isolates carrying $\mathrm{R}$ factors of group $\mathrm{N}$ have been obtained from Athens, London, Boston and New Jersey. Plasmids of this group were, thus, well represented in the $\mathrm{R}$ factor set from $P$. mirabilis/P. vulgaris. They were abundant among plasmids from $P$. rettgeri and $P$. morganii and were also observed in isolates of Providencia.

Plac, R665, R704b and R87r. Plasmids of the A-C complex (Hedges, I974) were transferred from $P$. mirabilis/P. vulgaris isolates from Germany, U.K., U.S.A. and Canada. They therefore seem widespread in this species, although much less abundant than in Providencia. It may be significant that three of the A-C plasmids came from sources which had supplied Providencia isolates carrying A-C plasmids (West Middlesex Hospital, London; Shaughnessy Hospital, Vancouver, Canada; University of Utah Medical Center, Salt Lake City, U.S.A.).

$R 436 a, R 437 a, R 438, R 439, R 440, R 702$ and $R 940$. Plasmids of group P were reported in P. mirabilis/P. vulgaris by Roe, Jones \& Lowbury (1971). The properties of R702 have been described by Hedges \& Jacob (1974). Although plasmids of this group have been detected in a wide range of genera, $P$. mirabilis/P. vulgaris is the first species in which plasmids with three distinct resistance patterns have been observed.

As with RP4 (Datta et al. I97I) the efficiency of transfer of these plasmids was reduced by the presence of R64 (or other members of compatibility group I $\alpha$ ) in the donor (Table 4).

RtsI. This plasmid, transferred from an isolate of $P$. mirabilis/P. vulgaris (Terawaki, Takayasu \& Akiba, 1967), is one of the prototypes of group T. Other plasmids of this group have been detected only in $P$. rettgeri (Coetzee et al. 1972).

$R 705$ and $R 706$. These two plasmids, conferring resistance to kanamycin, are apparently identical with $\mathrm{R}$ factors such as $\mathrm{R}_{39} \mathrm{I}$ and $\mathrm{R} 748$, transferred from $P$. rettgeri (Coetzee et al. 1972) and Providencia (Hedges, I974), respectively. All came from strains isolated in Pretoria. All are provisionally assigned to group $\mathrm{J}$, but because of identity of genetic markers direct testing has not been possible.

$R 753, R 754, R 755, R 757 a, R 769, R 770, R 901, R 902, R 903$ and $R 905$. These R factors were all transmissible into $E$. coli $\mathrm{KI} 2$ strains but were very unstably inherited, often being lost during replication of an $\mathrm{R}^{+} E$. coli culture unless selection against $\mathrm{R}^{-}$segregants was 


\section{Table 5. Compatibility properties of representative plasmids of group $V$}

The selective medium was MacConkey agar+rifampicin + kanamycin. The donor was Pmr3A (R769-1); a segregant of $R_{769}$ which had lost the chloramphenicol resistance determinant (i.e. it conferred resistance to streptomycin, kanamycin and sulphonamides).

\begin{tabular}{|c|c|c|c|}
\hline \multirow[b]{2}{*}{ Recipient } & \multirow{2}{*}{$\begin{array}{l}\text { Frequency of } \\
\text { transfer* }\end{array}$} & \multicolumn{2}{|c|}{ Unselected marker phenotypes $\dagger$} \\
\hline & & Chromsomal & Plasmid \\
\hline $\begin{array}{l}\text { Pmi3-B } \\
\text { Pmi3-B(R753) }\end{array}$ & 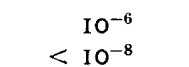 & $\begin{array}{l}24 / 24 \mathrm{~N}^{8} \\
24 / 24 \mathrm{~N}^{8}\end{array}$ & $\begin{array}{l}23 A^{\mathrm{B}} C^{8}: \text { : } A^{R} \\
23 A^{8} C^{8}: I A^{R} C\end{array}$ \\
\hline PmI3-B(R905) & $<10^{-8}$ & $24 / 24 \mathrm{~N}^{8}$ & $21 C^{s}: 3 C^{R} \ddagger$ \\
\hline
\end{tabular}

* Frequencies quoted refer to I h matings by the method of Dennison (1972). Where no transfer was noted in these matings, overnight mating mixtures were sampled.

$\dagger \mathrm{N}$, nalidixic acid. For other abbreviations see Table $\mathbf{I}$.

† These were stable recombinants conferring all resistances determined by the two parental plasmids.

maintained. On average, an overnight culture in drug-free broth (started from a single colony on agar containing a drug selective for $\mathrm{R}^{+}$clones) contained about $10 \% \mathrm{R}^{+}$cells. It was therefore impossible to test whether these plasmids could be eliminated from an $E$. coli host by entry of an incompatible plasmid. It was, however, possible to demonstrate that plasmids of this group could be transferred into strains of $E$. coli $\mathrm{KI}$, carrying representative plasmids of all compatibility groups so far defined, without elimination of the resident plasmid. The doubles were stable so long as selection was maintained for the unstably inherited plasmid and both plasmids were separately transferable. Thus, these plasmids did not belong to any known compatibility group.

From E. coli hosts, the plasmids were transferred to strains of Pmr3. In this host (as in the natural $P$. mirabilis/P. vulgaris isolates in which they were originally detected) the $\mathbf{R}$ factors were stably inherited; overnight cultures in drug-free broth usually contained 99 to $100 \% \mathrm{R}^{+}$cells.

The results of experiments on the conjugal transfer of plasmids between $R^{+} \mathrm{PmI} 3$ strains showed that all these plasmids constitute a single compatibility group (named $\mathrm{V}$, in honour of Dr Vyvyan Salisbury). Table 5 shows examples of the results for matings involving three of these R factors, one from Japan, one from Thailand and one (a spontaneous segregant, lacking chloramphenicol resistance, of a plasmid) from India. These crosses show incompatibility, surface exclusion and recombination between plasmids of group $\mathrm{V}$.

Plasmids of group $\mathrm{V}$ have not been observed in natural isolates of any species other than $P$. mirabilis $/ P$. vulgaris. They are clearly adapted to these species to the extent that they cannot efficiently replicate and undergo segregation in E. coli KI 2. The geographical origins of the $\mathrm{V}^{+} P$. mirabilis/ $P$. vulgaris are remarkable; all came from Asia (India, Thailand and Japan) and among the strains isolated in this continent $V$ plasmids are the most abundant group. Yet not a single $\mathrm{V}^{+} P$. mirabilis/P. vulgaris strain was found among the large numbers of isolates from Europe, North America or South Africa. It will be interesting to map the geographical distribution pattern of $\mathrm{V}$ plasmid carrying strains.

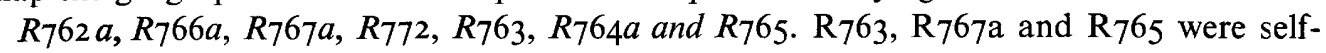
transmissible plasmids conferring resistance to ampicillin, streptomycin and tetracycline. $\mathbf{R}_{763}$, selected as a representative plasmid of this group, was compatible with plasmids of all groups testable (no suitable plasmids of groups FIV, G or X were available).

R762a, R766a, R767a and R772 were NST plasmids conferring resistance to kanamycin. Plasmids of all testable groups (no suitable plasmid of group $\mathbf{J}$ was available) were trans- 


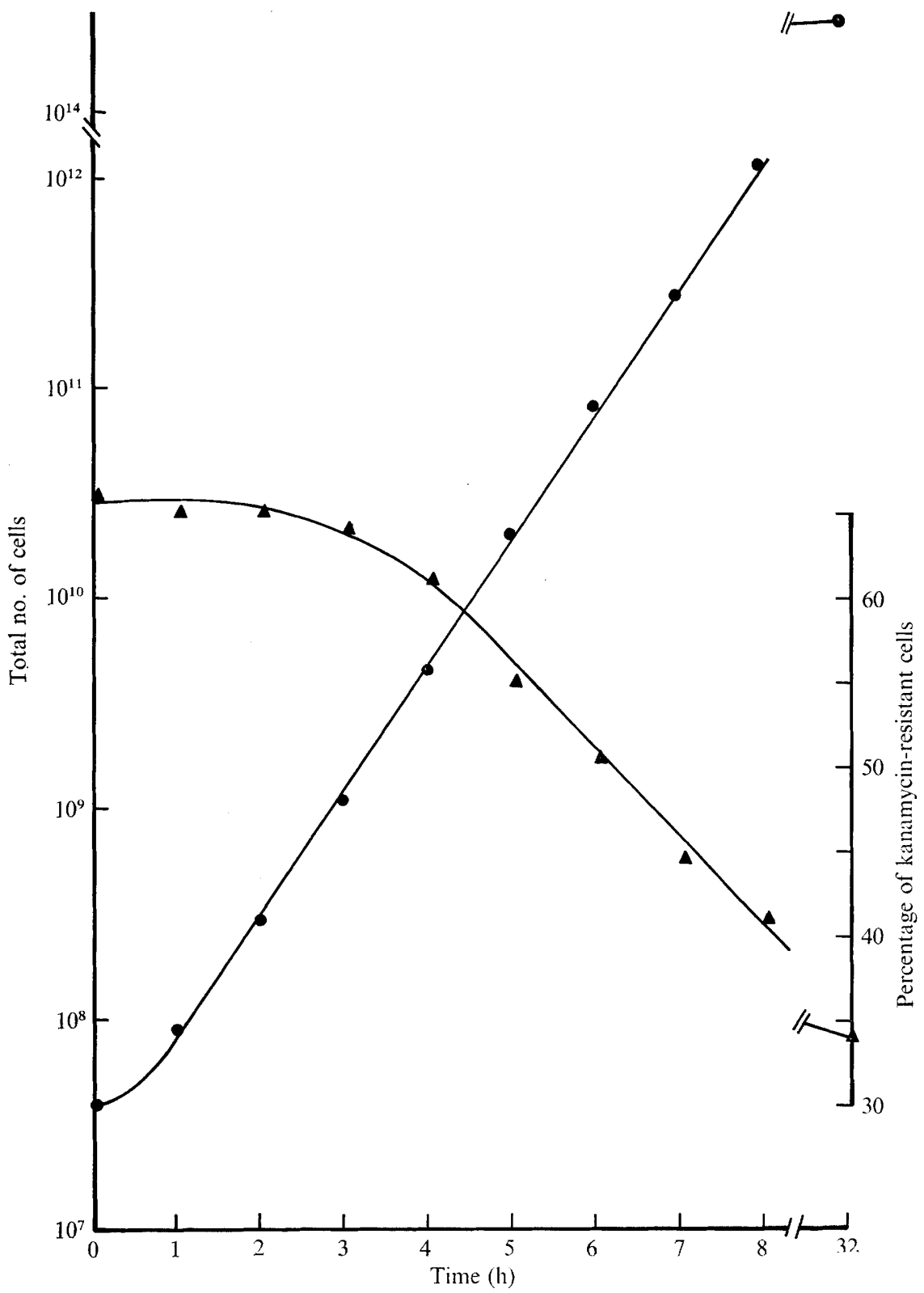

Fig. I. Cells from a single colony of $\mathrm{J}_{53-2}\left(\mathrm{R}_{7} 62 \mathrm{a}\right)(\mathrm{R} 763)$ were transferred to prewarmed, drug-free nutrient broth and incubated at $37^{\circ} \mathrm{C}$ without shaking. By repeated dilution with fresh, prewarmed broth the concentration of bacterial cells was maintained between $5 \times 10^{6}$ and $5 \times 10^{7} / \mathrm{ml}$ for $8 \mathrm{~h}$. After this the culture was allowed to attain stationary phase by incubation overnight without further dilution. The kinetics of increase in cell numbers is shown by curve $A$ and the decline in the proportion of kanamycin-resistant $\left(\mathrm{R}_{7} 62 \mathrm{a}^{+}\right)$cells is shown by curve B. No cells which had lost $\mathrm{R}_{763}$ were detected in these experiments 
ferred into $\mathrm{J}_{53}-2\left(R_{7} 62 \mathrm{a}\right)$. None of the 'standard' plasmids caused elimination of $R_{7} 62 \mathrm{a}$, but entry of $R_{76} 6_{3} R_{764 a}$ or $R_{765}$ did. When $R_{763}$ was transferred into J53-2(R762a) and transcipients selected on medium containing both ampicillin and kanamycin, the transcipient clones were found to carry both plasmids. These doubles were stable so long as kanamycin was present (i.e. selection for retention of R762a was maintained). During growth in drugfree media, however, $\mathrm{R}_{762 \mathrm{a}}$ was rapidly eliminated. Regardless of the presence of antibiotics, R793 was inherited stably.

Figure I shows the kinetics of loss of kanamycin resistance (i.e. R762a) from a double during growth in drug-free nutrient broth. The most striking feature of this process is the fact that no significant loss of the plasmid occurred during the first $3 \mathrm{~h}$ of growth (immediately after inoculation of the broth from a single colony on an agar plate containing kanamycin), although exponential growth began after less than $\mathrm{I} h$. The fact that more than $30 \%$ of the cells in the culture were kanamycin sensitive from the outset shows that loss of R762a had taken place during the development of the colony despite the presence of kanamycin in the plate. So the failure to observe increase in the proportion of $\mathrm{R}_{7} 62 \mathrm{a}^{-}$segregants cannot be explained by selective effects of very small amounts of kanamycin carried from the plate to the broth. The most plausible interpretation of these results is that the replication of R762a resembles that of R6K (Kontomichalou et al. 1970). In exponentially-growing culture, the plasmid replicates under stringent control; when the culture approaches the stationary phase, the regulation of plasmid replication is relaxed and the number of copies per cell increases. Suppose the tendency of $\mathrm{R} 762 \mathrm{a}$ to replicate faster than cell division in cells which are entering stationary phase overcomes the tendency of $R 763$ to eliminate R762a during this phase of growth. Then the cells of the colony transferred to broth would have to undergo several rounds of replication to reduce the abundance of $R_{7} 62 \mathrm{a}$ plasmids sufficiently to permit the formation of $\mathrm{R}_{7} 62 \mathrm{a}^{-}$segregants.

This model is confirmed by the observation that although $\mathrm{R}_{7} 62 \mathrm{a}^{-}$segregants were produced while the culture was regularly diluted so as to keep the cell concentration below $10^{8} / \mathrm{ml}$, very few were formed when the culture was subsequently left to grow to saturation over night.

It is not clear whether these plasmids should be regarded as constituting a new compatibility group. The unilateral elimination of $\mathrm{R}_{7} 62 \mathrm{a}$ ( $\mathrm{R}_{7} 63$ was never eliminated in any of the experiments) could be explained as an extreme example of hierarchy among pairs of incompatible plasmids (MacFarren \& Clowes, I967; Datta, Hedges, Becker \& Davies, I974). However, the absolute failure to obtain recombinants between $\mathrm{R}_{762 \mathrm{a}}$ and $\mathrm{R}_{7} 63$ suggests that there is no substantial region of genetic homology between these two plasmids. It therefore seems premature to designate a new compatibility group to contain these plasmids.

\section{REFERENCES}

BARTh, P. T. \& Grinter, N. J. (1974). Comparison of the deoxyribonucleic acid molecular weights and homologies of plasmids conferring linked resistance to streptomycin and sulphonomides. Journal of Bacteriology (in the Press).

Brenner, D. J. \& Falkow, S. (1971). Molecular relationships among members of the Enterobacteriaceae. Advances in Genetics $16,8 \mathrm{I}-\mathrm{I}$ I 8.

ChaI, K. H. \& Soo-Hoo, T. S. (1970). The antibiogram and the distribution of Proteus organisms isolated from urinary tracts. Medical Journal of Malaya 25, 43-45.

Coetzee, J. N. (1963). Transduction of swarming in Proteus mirabilis. Journal of General Microbiology 33, $1-7$.

Coetzee, J. N. (1972). Genetics of the Proteus group. Annual Review of Microbiology 26, 23-54. 
Coetzee, J. N., Datta, N. \& Hedges, R. W. (1972). R factors from Proteus rettgeri. Journal of General Microbiology 72, 543-552.

Coetzee, J. N. \& SACKS, T. G. (1960). Transduction of streptomycin resistance in Proteus mirabilis. Journal of General Microbiology 23, 445-455.

CoHEN, S. N. \& Miller, C. A. (I970). Non-chromosomal antibiotic resistance in bacteria. III. Isolation of the discrete transfer unit of the R factor RI. Proceedings of the National Academy of Sciences of the United States of America 67, 510-516.

Datta, N. (I974). Epidemiology and classification of plasmids. Booklet No. 60502 of the American Society for Microbiology, Baltimore.

Datta, N. \& Hedges, R. W. (I972a). R factors identified in Paris, some conferring gentamicin resistance, constitute a new compatibility group. Annales de l'Institut Pasteur 123, 879-883.

DattA, N. \& HedGes, R. W. (1972 b). Trimethoprim resistance conferred by plasmids in Enterobacteriaceae. Journal of General Microbiology 72, 349-356.

Datta, N. \& Hedges, R. W. (1973). R factors of compatibility group A. Journal of General Microbiology 74, $335-336$.

Datta, N., Hedges, R. W., Becker, D. \& Davies, J. (1974). Plasmid-determined fusidic acid resistance in the Enterobacteriaceae. Journal of General Microbiology 83, I9I-I96.

Datta, N., Hedges, R. W., Shaw, E. J., Sykes, R. B. \& Richmond, M. H. (197I). Properties of an R factor from Pseudomonas aeruginosa. Journal of Bacteriology 108, I 244-I 249.

Datta, N. \& Olarte, J. (I974). R factors in strains of Salmonella typhi and Shigella dysenteriae I isolated during epidemics in Mexico: classification by compatibility. Antimicrobial Agents and Chemotherapy $\mathbf{5}$, 310-317.

Dennison, S. (1972). Naturally occurring $R$ factor, derepressed for pilus synthesis, belonging to the same compatibility group as the sec factor F of Escherichia coli KI2. Journal of Bacteriology 109, 4I6-422.

Dikyı, B. N. (I97I). Sensitivity of various Proteus species to antibiotics. Antibiotiki 16, 622-624.

von Gravenitz A. \& Nourbakhsh, M. (1972). Antimicrobial resistance of the genera Proteus, Providence \& Serratia with special reference to multiple resistance patterns. Medical Microbiology and Immunology I57, I $42-148$.

Grindley, N. D. F., Grindley, J. N. \& Anderson, E. S. (1972). R factor compatibility groups. Molecular and General Genetics I19, 287-297.

Guo, M. M. S. \& LIU, P. V. (1965). Serological specificities of ureases of Proteus species. Journal of General Microbiology 38, 41 7-422.

HAuSER, G. (1885). Über Fäulniss-Bacterien. Leipzig: F. C. W. Vogel.

Hedges, R. W. (1972). Phenotypic characterization of $f^{-}$R factors determining the restriction and modification of hsp II specificity. Molecular and General Genetics Ir5, 225-233.

Hedges, R. W. (I974). R factors from Providence. Journal of General Microbiology 81, I7I-I 8I.

Hedges, R. W. \& Datta, N. (I97I). $f^{-}$R factors giving chloramphenicol resistance. Nature, London 234, 220-22I.

Hedges, R. W. \& DatTA, N. (I972). Ri24, an $f^{+}$R factor of a new compatibility class. Journal of General Microbiology 7r, 403-405.

Hedges, R. W. \& Datta, N. (I973). Plasmids determining I pili constitute a compatibility complex. Journal of General Microbiology 77, 19-25.

Hedges, R. W., Datta, N., Coetzee, J. N. \& Dennison, S. (I973). R factors from Proteus morganii. Journal of General Microbiology 77, 249-259.

Hedges, R. W. \& JACOB, A. E. (1974). Transposition of ampicillin resistance from RP4 to other replicons. Molecular and General Genetics 132, 31-40.

Hedges, R. W., JACOB, A. E. \& SMith, J. T. (1974a). Properties of an R factor from Bordetella bronchiseptica. Journal of General Microbiology 84, 199-204.

Hedges, R. W., Rodrigues-Lemoine, V. \& Datta, N. (I974b). R factors from Serratia marcescens. Journal of General Microbiology 86, 88-92.

IkedA, H. \& Tomizawa, J. I. (I968). Prophage Pr, an extrachromosomal replication unit. Cold Spring Harbor Symposia on Quantitative Biology 33, 79r-798.

JACOB, F. \& ADELBERG, E. A. (1959). Transfert de charactères génétiques par incorporation au facteur d'Escherichia coli. Comptes rendus hebdomadaires des séances de l'Academy des Sciences 249, I59-193.

JobanputRa, R. S. \& DatTA, N. (I974). Trimethoprim resistance factors in enterobacteria from clinical specimens. Journal of Medical Microbiology 7, 169-177.

KauffManN, F. (I95I). Enterobacteriaceae. Copenhagen: Ejear Munksgaard. 
KaUffManN, F. (1956). Zur biochemischen und serologischen Gruppen- und Typen-Einteilung der Enterobacteriaceae. Zentralblatt für Bakteriologie, Parasitenkunde, Infektionskrankheiten und Hygiene (Abteilung I) $165,344-354$.

Kontomichalou, P., Mitani, M. \& Clowes, R. C. (I970). Circular R factor molecules controlling penicillinase synthesis, replicating in Escherichia coli under relaxed or stringent control. Journal of Bacteriology 104, 34-44.

Lawn, A. M., Meynell, E., Meynell, G. G. \& Datta, N. (1967). Sex pili and the classification of sex factors in the Enterobacteriaceae. Nature, London 216, 343-346.

MacFarren, A. C. \& Clowes, R. C. (I967). A comparative study of two F like colicin factors col V2 and col $\mathrm{V}_{3}$ in Escherichia coli. Journal of Bacteriology 94, 365-377.

Meynell, E. \& DatTA, N. (1967). Mutant drug resistance factors of high transmissibility. Nature, London 214, 885-887.

Milliken, C. E. \& Clowes, R. C. (I973). Molecular structure of an R factor, its component drug-resistance determinants and transfer factor. Journal of Bacteriology I13, 1026-1033.

Mitsuhashi, S. (1969). The R factors. Journal of Infectious Diseases 199, 89-100.

OLSEN, R. H. \& SHIPLEY, P. (I973). Host range and properties of the Pseudomonas aeruginosa R factor RI 822 . Journal of Bacteriology $\mathbf{1 3}, 772-780$.

Roe, E., Jones, R. T. \& Lowbury, E. J. L. (I97I). Transfer of antibiotic resistance between Pseudomonas aeruginosa, Escherichia coli, and other Gram-negative bacilli in burns. Lancet i, I49-I52.

Smit, J. A. \& Coetzee, J. N. (I967). Serological specificities of phenylalanine deaminases of the ProteusProvidence group. Nature, London 214, I238-1239.

Smith, H. R., Humphreys, G. O. \& Anderson, E. S. (1974). Genetic and molecular characterization of some non-transferring plasmids. Molecular and General Genetics 129, 229-242.

Sмiтн, H. W. (1972). Ampicillin resistance in Escherichia coli determined by phage. Nature New Biology 238 , 205-206.

Terawaki, Y., Takayasu, H. \& Akiba, T. (1967). Thermosensitive replication of a kanamycin resistance factor. Journal of Bacteriology 94, 687-690.

Tomaschoff, E. (1969). Die Ökologie und Bedeutung der Proteus Gruppe. Klinische Wochenschrift 47, 837844 .

Witchitz, J. L. \& Gerbaud, G. R. (1972). Classification de plasmids conférant la résistance à la gentamicine. Annales de l'Institut Pasteur 123, 333-339. 